\title{
EFFECT OF TIME AND IBA CONCENTRATION ON THE PERFOR- MANCE OF BAY LEAF LAYERING
}

\author{
S N Mozumder ${ }^{1}$, M M Kamal ${ }^{2}$, M I Haque ${ }^{3}$ and M Shahiduzzaman ${ }^{4}$ \\ ${ }^{1}$ Principal Scientific Officer, Regional Spices Research Centre, Bangladesh Agricultural Research Institute (BARI), Gazipur, \\ Bangaldesh \\ ${ }^{2}$ Scientific Officer, Regional Spices Research Centre, Bangladesh Agricultural Research Institute (BARI), Gazipur, Ban- \\ galdesh \\ ${ }^{3}$ Senior Scientific Officer, Regional Spices Research Centre, Bangladesh Agricultural Research Institute (BARI), Gazipur, \\ Bangaldesh \\ ${ }^{4}$ Chief Scientific Officer, Regional Spices Research Centre, Bangladesh Agricultural Research Institute (BARI), Gazipur, \\ Bangladesh
}

Received 17 June 2021

Accepted 2 July 2021

Published 31 July 2021

Corresponding Author

S N Mozumder, shailenbari95@ya

hoo.com

DOI 10.29121/

granthaalayah.v9.i7.2021.4047

Funding: This research received no specific grant from any funding agency in the public, commercial, or not-for-profit sectors.

Copyright: (C) 2021 The Author(s). This is an open access article distributed under the terms of the Creative Commons Attribution License, which permits unrestricted use, distribution, and reproduction in any medium, provided the original author and source are credited.

\section{ABSTRACT}

The experiment was conducted in a factorial Complete Randomized Design (CRD) with six levels of IBA viz. 1000, 2000, 3000, 4000, 5000ppm and control (without IBA) with five times of layering in the middle $\left(15^{\text {th }}\right.$ ) of each April, May, June, July and August at the Regional Spices Research Centre, BARI, Gazipur during May 2017 to September 2018. Bay leaf layering was found very much unsuccessful with or without IBA treatment. Layering time and IBA concentration significantly influence on the success and rooting of layers under Bangladesh condition. May to July layering with 4000 ppm IBA treatment found better for successful air layering for vegetative propagation of bay leaf in Bangladesh.

Keywords: Performance, Leaf Layering, Effect

\section{INTRODUCTION}

Bay leaf is a high valued spices having valuable aroma, higher nutritive and medicinal value widely used in Bangladesh for preparation of many kinds of foods, beverage, cosmetics and medicines. The demands are usually meet up by importing from other countries which required a huge expenditure. The quality of imported bay leaf is poor due to admixture, sub-standard processing and long storage and transport duration. Production of bay leaf can be increased using BARI released Bay leaf (BARI Bay leaf-1) variety having better aroma, higher leaf yield and stress tolerant habit. Homesteads, hilly and highlands are suitable for their cultivation. Lack of quality saplings are the major constraints for expanding the growing area. Standard vegetative propagation technology of Bay leaf has not yet been standardized in Bangladesh. Development 
of appropriate vegetative propagation techniques of Bay leaf for rapid dissemination of high yielding varieties (BARI Bay leaf-1) is essential to ensure quality bay leaf production. To increase bay leaf production, intensive research on propagation is very much essential in our country. However the study is therefore, undertaken to standardize the propagation techniques using optimum strength of rooting hormone (IBA) concentration and layering time for rapid multiplication of bay leaf to ensure quality sapling production.

\section{MATERIALS AND METHOD}

The experiment was conducted in a factorial Complete Randomized Design (CRD) with six levels of IBA viz. 1000, 2000, 3000, 4000, 5000ppm and control (without IBA) with five times of layering in the middle $\left(15^{\text {th }}\right)$ of each April, May, June, July and August at the Regional Spices Research Centre, BARI, Gazipur during May 2017 to September 2018. Proximal slanting cut end of 30 cuttings for each treatment were placed in the hormone solutions for five minutes then kept 15 minutes to discard extra solution. After treating with hormone, the cuttings were planted in the $15 \mathrm{~cm}$ raised beds of soil, sand and compost mixture at a spacing of $15 \times 10 \mathrm{~cm}$. For better water holding capacity and root development in layering, soil mixture was prepared with 50\% loamy soil and 50\% well decomposed cow dung and kept open for 2 weeks. Treatment wise hormone solution was taken with a small glass dropper pot applied on the cut surface (from where bark was removed) of the shoot. No hormone was applied for control treatment. Each replication of a single treatment consisting 10 layering shoots and a total of 30 for 3 replications was used and tagged properly. The stool or gooti (air layering) was made by covering the cut portion with $160-180 \mathrm{~g}$ of moist soil mixture, covered by polythene and tied tightly with jute rope. When a number of roots are established and visible through polythene, the air layering seems suitable to separate from the mother plant. A half cut was given at 1-2 cm below the stool of air layering. After one week, the layering was separated by gentle full cut from the previously cut place and extra branches and leaves were trimmed out. The trimmed layering shoot was planted in previously prepared polybag after removing the ploythene and kept one week under shade then 3 weeks in partial shade for establishment. Air layering seems suitable to plant in the field when a number of roots and shoots were established in polybag. Data on length and number of roots per layering was count breaking the stool just after detachment of layering. The samples of three live stools of layer were broken and the numbers of roots were counted and lengths of roots were measured with a digital slide calipers at 60 days after separation. After separation from the mother plants, success of detached layers and number of leaves were counted at 60 days of planting in the polybag. Data is taken on success rate, days to bud break, leaf and shoot growth, vigour of the saplings, establishment rate, disease and insect pest reaction. 


\section{RESULTS AND DISCUSSION}

\subsection{EFFECT OF TIME ON SUCCESS OF AIR LAYERING}

The time of layering had significantly affected the success of layering (Table 1 ). Early rooting was observed in May layering (51.8 days) which was statistically similar with April, June and July while August layering took more (68.1 days) for root visibility. Similar result was observed in separation of layers from the mother plant. Rooting success was similar in all five months but establishment rate was declined after June (Table 1, Figure 1 ).

Table 1 Effect of layering time on the performance of bay leaf

\begin{tabular}{cccccccccc}
\hline $\begin{array}{c}\text { Layer- } \\
\text { ing }\end{array}$ & $\begin{array}{c}\text { Days to } \\
\text { root } \\
\text { visible }\end{array}$ & $\begin{array}{c}\text { Days } \\
\text { to } \\
\text { cut }\end{array}$ & $\begin{array}{c}\text { \% } \\
\text { root- } \\
\text { ing }\end{array}$ & $\begin{array}{c}\text { Estab- } \\
\text { lish (\% } \\
\text { 60 DAS) }\end{array}$ & $\begin{array}{c}\text { \% } \\
\text { Dead at } \\
\text { 60 DAS }\end{array}$ & $\begin{array}{c}\text { Roots } \\
\text { /Layer }\end{array}$ & $\begin{array}{c}\text { Length } \\
\text { of root } \\
\text { (cm) }\end{array}$ & $\begin{array}{c}\text { Branch } \\
\text { Leaves } \\
\text { /layer }\end{array}$ \\
\hline April & $54.2 \mathrm{~b}$ & $72.6 \mathrm{~b}$ & 42.78 & $81.82 \mathrm{a}$ & $17.09 \mathrm{e}$ & $3.37 \mathrm{~b}$ & $7.27 \mathrm{~b}$ & $3.06 \mathrm{a}$ & $4.41 \mathrm{~b}$ \\
\hline May & $51.8 \mathrm{~b}$ & $71.4 \mathrm{bc}$ & 52.22 & $76.60 \mathrm{a}$ & $30.44 \mathrm{c}$ & $4.31 \mathrm{a}$ & $8.48 \mathrm{a}$ & $2.18 \mathrm{~b}$ & $5.18 \mathrm{a}$ \\
\hline June & $53.0 \mathrm{~b}$ & $71.9 \mathrm{bc}$ & 51.11 & $77.17 \mathrm{a}$ & $26.22 \mathrm{~d}$ & $4.41 \mathrm{a}$ & $8.49 \mathrm{a}$ & $2.25 \mathrm{~b}$ & $5.44 \mathrm{a}$ \\
\hline July & $53.0 \mathrm{~b}$ & $68.5 \mathrm{c}$ & 55.56 & $68.00 \mathrm{~b}$ & $42.79 \mathrm{~b}$ & $3.63 \mathrm{ab}$ & $6.74 \mathrm{a}$ & $1.81 \mathrm{c}$ & $4.65 \mathrm{ab}$ \\
\hline August & $68.1 \mathrm{a}$ & $87.7 \mathrm{a}$ & 53.33 & $51.04 \mathrm{c}$ & $47.94 \mathrm{a}$ & $3.59 \mathrm{ab}$ & $6.21 \mathrm{c}$ & $1.86 \mathrm{c}$ & $4.61 \mathrm{ab}$ \\
\hline $\begin{array}{c}\text { Signifi- } \\
\text { cance }\end{array}$ & $* 4.15$ & $*$ & $\mathrm{NS}$ & $* 6.68$ & $* * 8.61$ & $* 6.09$ & $* 6.07$ & $*$ & $* 6.41$ \\
CV\% & & 3.95 & 6.80 & & & & & 10.64 & \\
\hline
\end{tabular}

Means having same letter(s) or without letter are not significantly different by DMRT. 'ns' '*' and'**' means not significant, significant at $5 \%$ and $1 \%$ probability level, respectively.

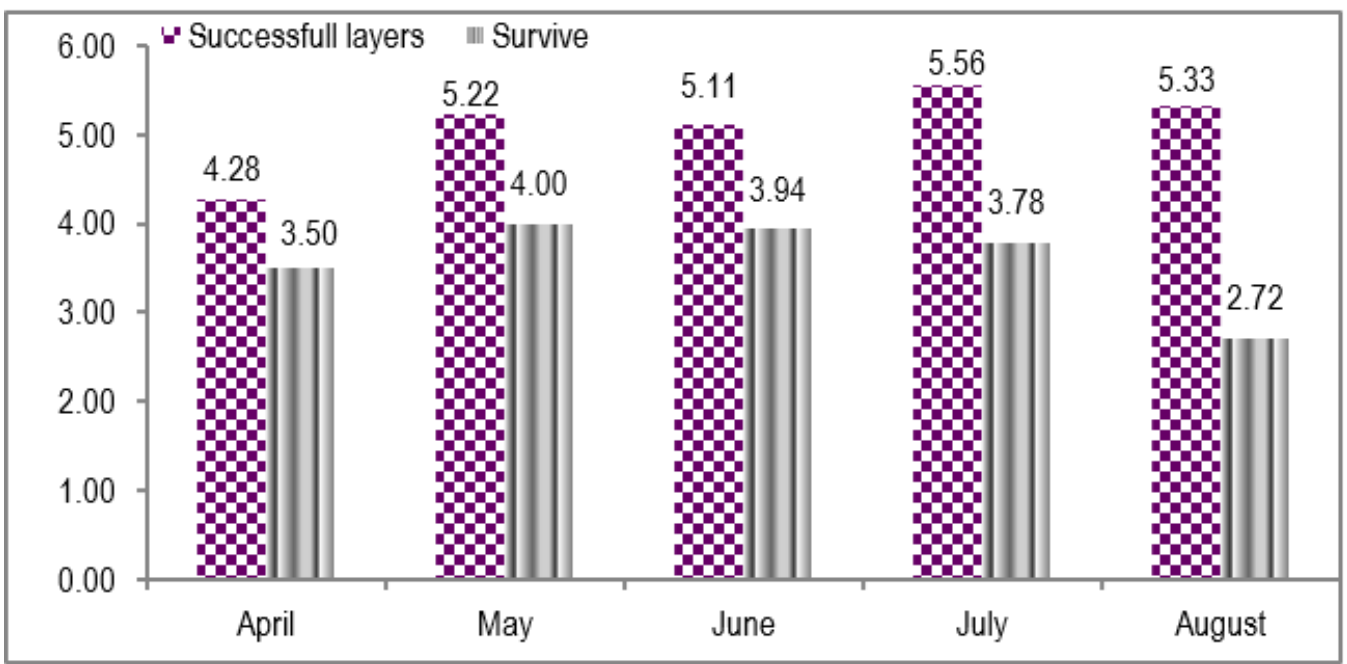

Figure 1 Success and establishment of bay leaf layering at different layering time.

Successful layer was slightly higher (5.56) in July layering (Figure 1) where higher percentage of rooting (55.56\%) also initiated in July layering but establishment rate was higher (81.82\%) in April as well as lower establishment rate was recorded 
(51.04\%) in August layering (Table 1 ). Successful layer was lower (2.72) in August layering (Figure 1 )

Death rate of detached layer was higher (47.94\%) in August layering and it was minimum in April (17.09\%). The lower success in August layering might be due to fall of temperature and lower humidity in October delayed and hampered rooting as well as shoot initiation.

The effect of time of layering was significantly affected on the death of detached layers, number and length of roots, and leaves per layers (Table 1.1). May and June layering gave more number $(\geq 4)$ of longer $(\geq 8 \mathrm{~cm})$ roots, and leaves $(\geq 5)$ compared to May, July and August layering. Hot humid weather favors rooting and leaf initiation that caused more rooting and leaves in May and June than April and August layering.

\section{EFFECT OF IBA CONCENTRATION ON BAY LEAF LAYERING}

IBA concentration had significant effect on rooting and success of air layering in bay leaf (Table 2, Figure 2 ). Control treatment and lower dose of IBA took more times to initiate roots compared to higher doses of IBA concentrations. Days to separation of layers from the mother plant was not significantly affected by IBA concentration. The number of successful layer was significantly higher (7.13) and highest rooting (71.33\%) found in $4000 \mathrm{ppm}$ IBA concentration followed by $5000 \mathrm{ppm}$ where number of successful layer was 6.87 and the highest (75.91\%) establishment at 60 days was recorded and it was lower(10\%) in control.

The number of established layer was significantly higher (78.69\%) in 4000ppm of IBA application followed by 5000 ppm IBA (75.91\%) and it was lower in control (16.67\%). These findings are resembled with the findings of Sharma and Aier (1989) the highest rooting percentage in plum was obtained with IBA treatment of cuttings with $2000 \mathrm{mg} \mathrm{l}^{-1}$ during summer.

Table 2 Effect of IBA concentrations on the performance of Bay leaf layering

\begin{tabular}{cccccccccc}
\hline $\begin{array}{c}\text { IBA } \\
\text { Conc. } \\
\text { ppm) }\end{array}$ & $\begin{array}{c}\text { Days to } \\
\text { root } \\
\text { visible }\end{array}$ & $\begin{array}{c}\text { Days } \\
\text { to } \\
\text { cut }\end{array}$ & $\begin{array}{c}\text { Root- } \\
\text { ing } \\
\text { (\%) }\end{array}$ & $\begin{array}{c}\text { Estab- } \\
\text { lish (\%) } \\
\text { 60 DAS }\end{array}$ & $\begin{array}{c}\text { \% } \\
\text { Dead } \\
\text { at 60 } \\
\text { DAS }\end{array}$ & $\begin{array}{c}\text { Roots } \\
\text { /Layer }\end{array}$ & $\begin{array}{c}\text { Length } \\
\text { of root } \\
\text { (cm) }\end{array}$ & $\begin{array}{c}\text { No } \\
\text { branc }\end{array}$ & $\begin{array}{c}\text { Leaves } \\
\text { /layer }\end{array}$ \\
\hline 1000 & $58.6 \mathrm{~b}$ & $74.7 \mathrm{~b}$ & $36.67 \mathrm{~b}$ & $56.22 \mathrm{c}$ & $43.78 \mathrm{~b}$ & $4.20 \mathrm{a}$ & $8.31 \mathrm{a}$ & $2.14 \mathrm{ak}$ & $5.12 \mathrm{a}$ \\
\hline 2000 & $56.5 \mathrm{~b}$ & $73.4 \mathrm{~b}$ & $54.00 \mathrm{al}$ & $71.78 \mathrm{ab}$ & $28.22 \mathrm{c}$ & $4.05 \mathrm{a}$ & $8.25 \mathrm{a}$ & $2.09 \mathrm{at}$ & $5.70 \mathrm{a}$ \\
\hline 3000 & $51.7 \mathrm{c}$ & $69.5 \mathrm{c}$ & $65.33 \mathrm{a}$ & $70.02 \mathrm{ab}$ & $29.98 \mathrm{c}$ & $4.52 \mathrm{a}$ & $8.43 \mathrm{a}$ & $3.83 \mathrm{a}$ & $5.72 \mathrm{a}$ \\
\hline 4000 & $49.7 \mathrm{c}$ & $69.3 \mathrm{c}$ & $71.33 \mathrm{a}$ & $78.69 \mathrm{a}$ & $21.31 \mathrm{~d}$ & $4.57 \mathrm{a}$ & $8.39 \mathrm{a}$ & $2.27 \mathrm{ak}$ & $5.82 \mathrm{a}$ \\
\hline 5000 & $49.7 \mathrm{c}$ & $69.9 \mathrm{c}$ & $68.67 \mathrm{a}$ & $75.91 \mathrm{a}$ & $24.09 \mathrm{~d}$ & $4.50 \mathrm{a}$ & $8.33 \mathrm{a}$ & $2.31 \mathrm{at}$ & $5.72 \mathrm{a}$ \\
\hline Control & $69.9 \mathrm{a}$ & $89.8 \mathrm{a}$ & $10.00 \mathrm{c}$ & $16.67 \mathrm{~d}$ & $50.00 \mathrm{a}$ & $1.33 \mathrm{~b}$ & $2.93 \mathrm{~b}$ & $0.75 \mathrm{~b}$ & $1.07 \mathrm{~b}$ \\
\hline $\begin{array}{c}\text { Signifi- } \\
\text { cance }\end{array}$ & $\mathrm{NS} 4.15$ & $\mathrm{NS}$ & $*$ & $* 6.68$ & $* 8.61$ & $* 6.09$ & $* 6.07$ & $*$ & $* 6.41$ \\
CV\% & & 3.95 & 6.80 & & & & & 10.64 & \\
\hline
\end{tabular}

Means having same letter(s) or without letter are not significantly different by DMRT. 'ns' '*' and'**' means not significant, significant at $5 \%$ and $1 \%$ probability level, respectively. 
Southworth and Dirr (1996) obtained the maximum success (87.5\%) of plum cuttings from 1500 ppm K-IBA solution. Neto et al. (2006) and Canli and Sefer (2009) obtained the highest success using 1000 ppm IBA in cherry cutting and layering. Indole-butyric-acid (IBA) enhanced root development and root growth by enhancing cell division resulted the maximum success of layering compared to control and lower level of IBA concentration (Mozumder et. al., 2014).

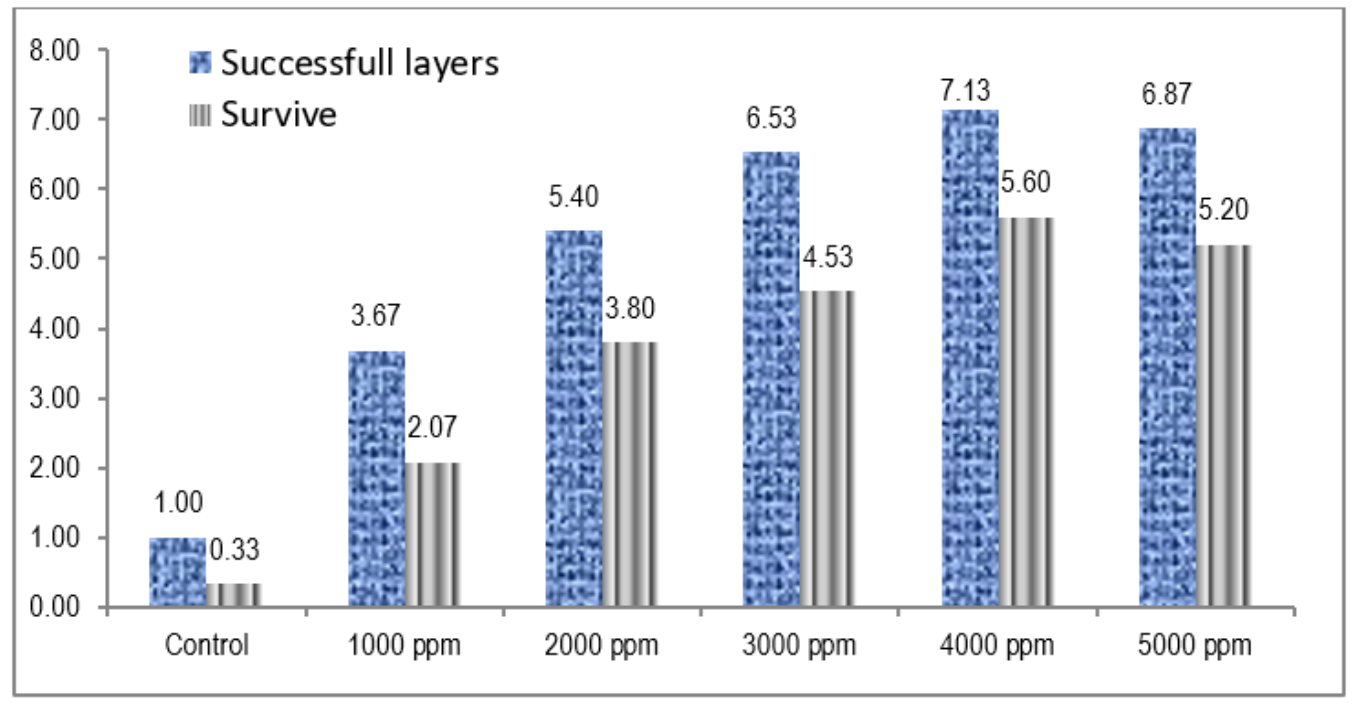

Figure 2 Success and establishment rate of bay leaf layering at different IBA concentration

There was significant variation of death of layers after detaching from the mother plant, rooting and leaf production with various levels of IBA treatment (Table 2 ). A number of air layering shoots were died in the poly bag after separation from the mother plant. Application of IBA resulted more number $(\geq 4)$ of longer $(\geq 8 \mathrm{~cm})$ roots compared to control. Numbers of leaves were increased with increasing IBA concentration. The highest number of leaves (5.82/layer) was recorded from the application of $4000 \mathrm{ppm}$ IBA which was statically similar in all IBA levels and it was the lowest (1.07/layer) in control. IBA helps to accelerate cell division and root initiation in upper parts of the cut portion of the plant resulted more rooting and leaves with higher doses of IBA.

\section{COMBINED EFFECT OF TIME AND IBA CONCENTRATION IN BAY LEAF LAYERING}

Layering time and IBA concentration showed significant effect on rooting and success rate of layers (Table $3 \mathrm{a}$ and $3 \mathrm{~b}$ ) in bay leaf. August layering with lower concentration of IBA or control treatment took more 2-3 days compared to April, May, June and July month's layering for root initiation and separation of layers from the mother plant. Early rooting (45.3 days) was found in May layering with 4000ppm 
while it was significantly delayed (83.7 days) in August layering without IBA treatment. Bay leaf layers took about 8 weeks to separation that was slightly affected due to layering time but greatly for hormone application. Singh and Ray (2011) opined that IBA concentration and layering time influence on success of layering in Ficus sp. The number of successful layer was significantly higher in July layering (7.67, $76.67 \%$ ) with 4000ppm IBA closely followed by May and August (7.33, 73.33\%)with same level IBA application and the success was almost nil $(0.33,3.33 \%)$ in April and August layering without IBA.

The lower success in August layering with low IBA is due to fall of temperature and lower hormonal activity hampered rooting. No layer was survived finally from April, July and August layering without IBA application.

Significant variations on survivability of layers after detaching from mother plant, rooting and leaf production due to layering time with various IBA concentrations (Table 1.3.a and 1.3.b). The maximum number and rate of survive layers (6.33, 83.31\%) was found in May layering with 4000 ppm IBA treatment and it was statistically similar with April Layering (5.67, 89.61\%) with 5000 ppm IBA while it was nil (0\%) in April, July and August layering without IBA application. Higher concentration IBA results more number of roots in early June-July layering compared to control and lower concentration of IBA treatment in later layering might be the cause of such variation. The number and length of root did not differ significantly with the range of 2.53 to 4.67 and $7.17-9.33 \mathrm{~cm}$ per layers at 60 days with the combination of different IBA concentration with time of layering (Table $3 \mathrm{~b}$ ).

Number of branches and leaves were increased with increasing IBA concentration in all months of layering. Kakon et al. (2008) showed that among different varieties BARI guava- 1 showed the best performance with different concentrations of growth regulators had significant effect on almost all parameters. IBA at $1200 \mathrm{ppm}$ showed the best performance among the treatments.

The maximum number of leaves (6.31/layer) per layer was recorded from the application of 4000ppm IBA in May layering and lowest (2.0/layer) was found from control in the same time of layering. There was no successful layering in April, July and August without IBA that had no roots or leaves. IBA accelerate cell division and root initiation high temperature and humidity resulted more rooting and leaves with higher doses of IBA in May and June layering.Sing (2001) found that use of IBA was beneficial in enhancing the callus formation, number, length and diameter of both primary and secondary roots and survival of air-layered twigs. This findings are almost similar with the report of Rymbai and Reddy (2010) ) that air layers of guava have been successfully achieved by exogenous application of IBA at $4000 \mathrm{ppm}$. The result from these observations were partially resembled with some findings such as Sharma and Aier (1989) get maximum success with 2000 ppm IBA, Southworth and Dirr (1996) obtained from 1500 ppm IBA while Canli and Sefer (2009) and Neto et al. (2006) get the maximum success with 1000 ppm IBA concentration in plum. AS (1989) found that highest concentration of IBA $(5,000 \mathrm{ppm})$ proved significantly bet- 
Table 3 Combined effect of layering time and IBA on success of bay leaf propagation

\begin{tabular}{|c|c|c|c|c|c|c|}
\hline Time & $\begin{array}{c}\text { IBA } \\
\text { Conc. }\end{array}$ & $\begin{array}{c}\text { Days to root } \\
\text { visible }\end{array}$ & $\begin{array}{c}\text { Days to } \\
\text { Separation }\end{array}$ & $\begin{array}{c}\text { Successful } \\
\text { layers (nos) }\end{array}$ & $\begin{array}{c}\text { Root- } \\
\text { ing(\%) }\end{array}$ & $\begin{array}{c}\text { Survive (60 } \\
\text { DAS) }\end{array}$ \\
\hline \multirow[t]{6}{*}{ April } & 1000 & 58.0 & 75.7 & $3.00 \mathrm{~d}$ & $30.00 \mathrm{~d}$ & $1.67 \mathrm{ef}$ \\
\hline & 2000 & 54.3 & 73.0 & $4.33 \mathrm{~cd}$ & $43.33 \mathrm{~cd}$ & $3.67 \mathrm{~cd}$ \\
\hline & 3000 & 50.0 & 68.0 & $5.33 \mathrm{bc}$ & $53.33 \mathrm{bc}$ & $4.33 b c$ \\
\hline & 4000 & 48.3 & 67.0 & $6.67 a b$ & $66.67 a$ & $5.67 a b$ \\
\hline & 5000 & 48.3 & 67.0 & $6.33 b$ & 63.33ab & $5.67 \mathrm{ab}$ \\
\hline & $\begin{array}{l}\text { Con- } \\
\text { trol }\end{array}$ & 66.0 & 84.7 & $0.33 \mathrm{f}$ & 3.33 & $0.00 \mathrm{~g}$ \\
\hline \multirow[t]{6}{*}{ May } & 1000 & 54.7 & 73.7 & $4.00 c$ & $40.00 \mathrm{c}$ & $2.67 \mathrm{de}$ \\
\hline & 2000 & 51.3 & 70.7 & $5.00 \mathrm{bc}$ & $50.00 \mathrm{bc}$ & $4.00 c$ \\
\hline & 3000 & 47.7 & 66.0 & $6.67 a b$ & $66.67 \mathrm{a}$ & $5.00 \mathrm{bc}$ \\
\hline & 4000 & 45.3 & 66.0 & 7.33a & 73.33a & $6.33 a$ \\
\hline & 5000 & 45.7 & 66.0 & $6.67 \mathrm{ab}$ & $66.67 a$ & $5.33 \mathrm{~b}$ \\
\hline & $\begin{array}{l}\text { Con- } \\
\text { trol }\end{array}$ & 66.0 & 86.3 & $1.67 \mathrm{e}$ & $16.67 \mathrm{e}$ & $0.67 \mathrm{fg}$ \\
\hline \multirow[t]{6}{*}{ June } & 1000 & 56.3 & 71.7 & $3.67 \mathrm{~cd}$ & $36.67 \mathrm{~cd}$ & $2.67 \mathrm{de}$ \\
\hline & 2000 & 54.3 & 71.7 & $5.00 \mathrm{bc}$ & $50.00 \mathrm{bc}$ & $4.00 \mathrm{c}$ \\
\hline & 3000 & 47.7 & 67.3 & $6.33 \mathrm{ab}$ & 63.33ab & $5.00 \mathrm{bc}$ \\
\hline & 4000 & 46.7 & 67.3 & 7.00ab & $70.00 a$ & $5.67 a b$ \\
\hline & 5000 & 46.7 & 67.3 & $6.67 a b$ & $66.67 a$ & $5.33 \mathrm{~b}$ \\
\hline & $\begin{array}{l}\text { Con- } \\
\text { trol }\end{array}$ & 66.3 & 86.3 & $2.00 \mathrm{e}$ & $20.00 \mathrm{e}$ & $1.00 \mathrm{f}$ \\
\hline \multirow[t]{6}{*}{ July } & 1000 & 56.3 & 70.0 & $3.67 \mathrm{~cd}$ & $36.67 \mathrm{~cd}$ & $2.00 \mathrm{e}$ \\
\hline & 2000 & 53.7 & 68.7 & $6.67 \mathrm{ab}$ & $66.67 a$ & $4.67 \mathrm{bc}$ \\
\hline & 3000 & 48.0 & 65.0 & $7.00 \mathrm{ab}$ & $70.00 \mathrm{a}$ & $4.67 \mathrm{bc}$ \\
\hline & 4000 & 46.3 & 65.0 & $7.67 a$ & $76.67 a$ & 5.67ab \\
\hline & 5000 & 46.3 & 65.0 & $7.33 a$ & 73.33a & $5.67 \mathrm{ab}$ \\
\hline & $\begin{array}{l}\text { Con- } \\
\text { trol }\end{array}$ & 67.3 & 77.3 & $1.00 \mathrm{ef}$ & $10.00 \mathrm{ef}$ & $0.00 \mathrm{~g}$ \\
\hline \multirow[t]{6}{*}{ Augus1 } & 1000 & 67.7 & 82.7 & $4.00 \mathrm{~cd}$ & $40.00 \mathrm{~cd}$ & $1.33 \mathrm{ef}$ \\
\hline & 2000 & 68.7 & 83.0 & $6.00 \mathrm{bc}$ & $60.00 \mathrm{bc}$ & $2.67 \mathrm{de}$ \\
\hline & 3000 & 65.0 & 81.0 & $7.33 a$ & 73.33a & $3.67 \mathrm{~cd}$ \\
\hline & 4000 & 62.0 & 81.0 & $7.00 \mathrm{a}$ & $70.00 \mathrm{a}$ & $4.67 \mathrm{bc}$ \\
\hline & 5000 & 61.3 & 84.3 & $7.33 a$ & 73.33a & $4.00 c$ \\
\hline & $\begin{array}{l}\text { Con- } \\
\text { trol }\end{array}$ & 83.7 & 114.3 & $0.33 \mathrm{f}$ & $3.33 \mathrm{f}$ & $0.00 \mathrm{~g}$ \\
\hline \multicolumn{2}{|c|}{$\begin{array}{c}\text { Level of } \\
\text { Significance }\end{array}$} & NS & NS & * & * & * \\
\hline \multicolumn{2}{|c|}{$\mathrm{CV} \%$} & 4.15 & 3.95 & 6.80 & 6.80 & 7.59 \\
\hline
\end{tabular}

Means having same letter(s) or without letter are not significantly different by DMRT. 'ns' '*' and'**' means not significant, significant at $5 \%$ and $1 \%$ probability level, respectively. 
Table 4 Combined effect of layering time and IBA on success of bay leaf propagation

\begin{tabular}{|c|c|c|c|c|c|c|c|}
\hline Time & $\begin{array}{l}\text { IBA } \\
\text { Conc. }\end{array}$ & $\begin{array}{c}\text { Establish (\% } \\
60 \text { DAS) }\end{array}$ & $\begin{array}{c}\text { \% Dead at } \\
60 \text { DAS }\end{array}$ & $\begin{array}{l}\text { Roots } \\
\text { Layer }\end{array}$ & $\begin{array}{l}\text { Length of } \\
\operatorname{root}(\mathrm{cm})\end{array}$ & $\begin{array}{c}\text { Branch/ } \\
\text { layer }\end{array}$ & $\begin{array}{c}\text { Leaves } \\
\text { /layer }\end{array}$ \\
\hline \multirow[t]{6}{*}{ April } & 1000 & $55.56 c$ & 44.44 & 3.83 & 8.50 & $2.33 \mathrm{~b}$ & 4.50 \\
\hline & 2000 & $85.00 \mathrm{a}$ & 15.00 & 2.53 & 8.77 & $1.43 c$ & 5.59 \\
\hline & 3000 & $81.11 \mathrm{a}$ & 18.89 & 4.42 & 8.87 & $2.67 a$ & 5.57 \\
\hline & 4000 & $86.11 \mathrm{a}$ & 13.89 & 4.70 & 8.93 & $2.30 \mathrm{~b}$ & 5.44 \\
\hline & 5000 & 89.68a & 10.32 & 4.73 & 8.53 & $2.27 b$ & 5.38 \\
\hline & $\begin{array}{l}\text { Con- } \\
\text { trol }\end{array}$ & 0.00 & 100.0 & - & - & - & - \\
\hline \multirow[t]{6}{*}{ May } & 1000 & $64.44 \mathrm{bc}$ & 35.56 & 4.33 & 8.63 & $2.33 b$ & 5.10 \\
\hline & 2000 & $80.56 \mathrm{ab}$ & 19.44 & 4.61 & 8.57 & $2.17 \mathrm{~b}$ & 5.56 \\
\hline & 3000 & $73.57 b$ & 26.43 & 4.82 & 9.03 & $2.50 \mathrm{a}$ & 5.82 \\
\hline & 4000 & 86.31a & 13.69 & 4.78 & 9.10 & $2.27 \mathrm{~b}$ & 6.31 \\
\hline & 5000 & 79.17ab & 20.83 & 4.67 & 9.33 & $2.40 \mathrm{a}$ & 6.29 \\
\hline & $\begin{array}{l}\text { Con- } \\
\text { trol }\end{array}$ & $33.33 d$ & 66.67 & 2.67 & 6.20 & $1.40 \mathrm{c}$ & 2.00 \\
\hline \multirow[t]{6}{*}{ June } & 1000 & $72.22 b$ & 27.78 & 4.32 & 8.80 & $2.20 \mathrm{~b}$ & 5.33 \\
\hline & 2000 & $80.00 \mathrm{ab}$ & 20.00 & 4.52 & 8.20 & $2.27 \mathrm{~b}$ & 6.00 \\
\hline & 3000 & 79.37ab & 20.63 & 4.63 & 8.27 & $2.17 b$ & 6.07 \\
\hline & 4000 & $80.95 \mathrm{ab}$ & 19.05 & 4.56 & 8.27 & $2.28 b$ & 6.02 \\
\hline & 5000 & $80.16 a b$ & 19.84 & 4.43 & 9.00 & $2.23 \mathrm{~b}$ & 5.91 \\
\hline & $\begin{array}{l}\text { Con- } \\
\text { trol }\end{array}$ & $50.00 \mathrm{c}$ & 50.00 & 4.00 & 8.43 & $2.33 \mathrm{~b}$ & 3.33 \\
\hline \multirow[t]{6}{*}{ July } & 1000 & $55.56 \mathrm{bc}$ & 44.44 & 4.33 & 8.20 & $2.00 \mathrm{bc}$ & 5.50 \\
\hline & 2000 & $69.84 b c$ & 30.16 & 4.36 & 8.20 & $2.17 \mathrm{~b}$ & 5.53 \\
\hline & 3000 & $66.67 \mathrm{bc}$ & 33.33 & 4.37 & 8.30 & $2.30 \mathrm{~b}$ & 5.63 \\
\hline & 4000 & $73.81 b$ & 26.19 & 4.37 & 8.17 & $2.20 \mathrm{~b}$ & 5.65 \\
\hline & 5000 & $77.38 b$ & 22.62 & 4.35 & 7.60 & $2.21 b$ & 5.59 \\
\hline & $\begin{array}{l}\text { Con- } \\
\text { trol }\end{array}$ & 0.00 & 100.0 & - & - & - & - \\
\hline \multirow[t]{6}{*}{ Augus } & 1000 & $33.33 \mathrm{f}$ & 66.67 & 4.17 & 7.40 & $1.83 \mathrm{bc}$ & 5.17 \\
\hline & 2000 & $43.49 \mathrm{e}$ & 56.51 & 4.25 & 7.53 & $2.42 \mathrm{ab}$ & 5.83 \\
\hline & 3000 & 49.40de & 50.60 & 4.35 & 7.70 & $2.18 b$ & 5.52 \\
\hline & 4000 & $66.27 d$ & 33.73 & 4.44 & 7.47 & $2.31 \mathrm{~b}$ & 5.70 \\
\hline & 5000 & $53.17 \mathrm{~cd}$ & 46.83 & 4.33 & 7.17 & $2.44 \mathrm{ab}$ & 5.45 \\
\hline & $\begin{array}{l}\text { Con- } \\
\text { trol }\end{array}$ & 0.00 & 100.0 & - & - & - & - \\
\hline \multicolumn{2}{|c|}{$\begin{array}{c}\text { Significance } \\
\text { level CV\% }\end{array}$} & * 6.68 & * 8.61 & NS 6.09 & * 6.07 & $* 10.64$ & $* 6.41$ \\
\hline
\end{tabular}

Means having same letter(s) or without letter are not significantly different by DMRT. 'ns' '*' and'**' means not significant, significant at $5 \%$ and $1 \%$ probability level, respectively. 
ter for rooting and survival of air layers of Kagzi lime. All the findings were varied because those experiments were conducted in different plants species, environment, soils, climates and times.

\section{CONCLUSION}

Bay leaf layering was found very much unsuccessful with or without IBA treatment. Layering time and IBA concentration significantly influence on the success and rooting of layers under Bangladesh condition. May to July layering with 4000 ppm IBA treatment found better for successful air layering for vegetative propagation of bay leaf in Bangladesh.

\section{REFERENCES}

AS, Y. (1989). Effects of growth regulators and rooting media on callusing, rooting and survival of air layers of kagzi lime. Thesis submitted to JNKVV, Jabalpur for the degree of M.Sc. (Ag) (Unpublished).

Canli, F. A., \& Sefer, B. (2009). Effects of Indolebutyric Acid on Adventitious Root Formation from Semi-Hardwood Cuttings of 'Sarierik' Plum. J. Applied Biol. Sci, 3(1), 45-48.

Kakon, A. J., Haque, M. A., \& Mohsin, M. G. (2008). Effect of three growth regulators on mound layering in the three varieties of guava. SAARC. J. Agri, 6(2), 39-47.

Neto, M., Telles, U. R., Antonio, A. C., \& L, B. (2006). Rooting of hardwood cuttings from plum treated with indolbutiric acid. Cienc.Rural, 36(2), 448-452.

Rahman, N., Hussain, I., Imran, M., Jan, T., \& Awan, A. A. (2000). Effect of Different Concentrations of IBA on Rooting of Litchi (Litchi chinensis) in Air Layering. Pakistan Journal of Biological Sciences, 3(2), 330-331. Retrieved from https://dx.doi.org/10.3923/ pjbs.2000.330.331 10.3923/pjbs.2000.330.331

Rema, J., \&amp; Krishnamurthy, B., \& Mathew, P. A. (1997). Vegetative propagation of major tree spices, a review. India. Indian J. Spices and Aromatic Crops, 6(2), 87-105.

Rymbai, H., \& Reddy, G. S. (2010). Effect of IBA, time of layering and rooting media on airlayers and plantlets survival under different growing nursery conditions in guava. Special Issue, 67, 99-104.

Sándor, G. (2011).

Sharma, S. D., \& Aier, N. B. (1989). Seasonal rooting behaviour of cuttings of plum cultivars as influenced by IBA treatments. Scientia Horticulturae, 40(4), 297-303. Retrieved from https://dx.doi.org/10.1016/0304-4238(89)90103-9 10.1016/0304-4238(89)90103 $-9$

Singh, \& Ray, V. R. (2011). Effect of air layering time (season) with the aid of Indole Butyric Acid in Ficus krishnae and Ficus auriculata (Vol. 137). Indian Forester.

Southworth, A. L., \& Dirr, M. A. (1996). Timing and K-IBA Treatments Affect Rooting of Stem Cuttings of Cephalotaxus harringtonia. HortScience, 31(2), 222-223. Retrieved from https://dx.doi.org/10.21273/hortsci.31.2.222 10.21273/hortsci.31.2.222

Zaman, S., Hawlader, R. K., \& M. (1987). Simple Lessons from Biometry. Bangladesh Rice Research Institute. Gazipur. 